Article

\title{
Competence Literate but Context Lacking? Investigating the Potential of Study Abroad Programs to Promote Sustainability Competence Acquisition in Students
}

\author{
James Ayers $\mathbb{D}$ \\ Department of Strategic Sustainable Development, Blekinge Institute of Technology, \\ 37179 Karlskrona, Sweden; jya@bth.se
}

Received: 2 June 2020; Accepted: 30 June 2020; Published: 3 July 2020

\begin{abstract}
The examination of pedagogies that promote effective sustainability learning has led to vigorous academic discussion, as has research regarding the role of competence-based learning for sustainability. This paper investigates the role of a study abroad program, the Engineers without Borders Design Summit, in promoting the acquisition of sustainability competencies in its students. This study analysed both content of the program pedagogy and the written learning reflections of 137 student participants to examine if the program resulted in sustainability competence acquisition. The study's findings suggested that students did acquire sustainability competencies during the program, but also that students may become competence-literate but context-lacking as they acquire competency skillsets without understanding their purpose for use as sustainability tools or to promote sustainability outcomes. Therefore, this study recommends that competence-based education for sustainability requires situation of competence acquisition within sustainability contextualisation to ensure full competence potential is fulfilled. This study suggests that contextualisation can occur in a number of ways, including the use of defined sustainability principles as boundary conditions to frame learning environments, the use of sustainability epistemic teachers as "guides" to connect learning to sustainability and the facilitation of student experiences with unsustainability to promote personally motivated action towards sustainability.
\end{abstract}

Keywords: sustainability; education; competencies; study abroad; pedagogy

\section{Introduction}

\subsection{The Sustainability Challenge and Education for Sustainable Development}

Higher education institutions are tasked with the important challenge of equipping graduates with the skills and knowledge to address grand challenges facing the world. The ecological and social crisis now manifests as numerous, interconnected issues that include water scarcity, climate change, air pollution, social segregation and many other complex challenges that threaten the viability and integrity of global societies [1,2]. The immense task of halting the decreasing ecosystem quality that risks tipping the biosphere into a state in which it would be difficult or impossible to maintain the human civilization in now underway [3].

Higher education systems, and specifically Education for Sustainable Development (ESD), hold a significant role in developing individuals skilled to implement sustainability transitions. The promotion of "knowledge, skills, attitudes and values that empower learners to make informed decisions and responsible actions" [4] (p. 4) remains an integral leverage point in developing sustainable futures. While no single pedagogy or program holds a panacea response to sustainable development, education 
that shapes young people's life direction, self-identity, and relationship to broader social and cultural values and ethics [5] remains important if a generation of graduates are to become active professionals able to influence sustainability transitions and construct healthy, if not flourishing, socio-ecological systems. Research exploring effective ways to engage in sustainability education remains an ongoing academic discussion, one that holds diverse perspectives and highlights the potential of differing pedagogies in addressing and overcoming the sustainability crisis. Despite this, there is a shortage of empirical evidence regarding the ways in which pedagogies are successful in developing students sustainability competencies [6], an area this study aims to contribute to.

\subsection{The ESD Potential of Experiential Learning and Study Abroad}

The requirement of ESD to experiment with effective learning environments for sustainability has led to the revision of previously underutilized pedagogies, innovation of new ones and experimentation with approaches including collaborative, community-based and service learning [7]. While no single pedagogy can claim to answer all ESD needs, consensus is emerging regarding the role of pedagogies aimed at creating emancipatory and transformative learning in which students transcend the given, the ordinary, and the routine ways of doing to create new dynamic and alternative ways of seeing and doing [7], thus freeing themselves from the constraints of traditional thinking and its associated mindsets of business as usual and unsustainability. One such example of a transformative pedagogy is experiential learning. Defined as education that can comprise "carefully chosen experiences supported by reflection, critical analysis, and synthesis' [8] (p. 44), experiential learning has been regarded as an effective tool for sustainability education [8-10]. Originally developed by David Kolb who built on 20th century scholars John Dewey, Kurt Lewin and Jean Piaget [10] experiential theory is grounded in three major beliefs: that learning is not an outcome but a process, that it is continually grounded in experience, and that learning requires the resolution of conflicts dealing with opposing ways of dealing with the world [11].

One method of experiential learning is the concept of study abroad. While no singular understanding of study abroad suffices as a definition, an increasing array of international education programs have emerged recently that vary in length from one week to one-year [10] and usually incorporate international exchange. Study abroad education has increased in popularity in the last 25 years and aligns with experiential learning through its objective to stimulate the intellectual, social and emotional growth of the students [10]. By exposing participants to unique novel experiences, these programs encourage individuals to shift their current mindsets, beliefs and behaviors [12]. This outcome remains an important intervention point in leveraging mental shifts towards sustainability by breaking the bonds of unsustainable mindsets and behaviors and by encouraging critical context for understanding sustainability challenges. In this consideration, study abroad holds a significant potential in its ability to develop individuals able to guide sustainability transitions. Increasing interest in study abroad programs due to their reputation for positive international exchange has seen them grow in stature and use [5], and resulted in research that has highlighted benefits including development of world views, increased intercultural involvement and global understanding of participants [8], all outcomes that promote and align with holistic sustainability perspectives and the aims of Education for Sustainable Development. While the connection between study abroad pedagogy and sustainability learning is limited (and has concerns regarding the contradictory impacts of travel on the environment) the potential benefits for ESD provided by study abroad programs highlight a rationale for why they should be explored as an effective pedagogical tool within the field.

\subsection{The Ongoing Competencies Conversation in ESD}

An ongoing discussion in ESD research has centered around the use and value of competence-based learning for sustainability as an element to guide educational and pedagogical approaches considered by ESD educators and researchers. This discussion has been characterized by the sea of labels, terminological confusion and lack of consensus regarding what constitutes and defines a comprehensive 
set of sustainability competencies [13]. These issues have led to the slow progress of competence related outcomes in ESD research, teaching and learning. While difficulties with the development of tools for assessment and pedagogies for competence acquisition have also compounded the challenge [6]. Furthermore, some perspectives have examined competence development from the perspective of expertise, implying that competence development maintains instrumental approaches and limits the transmission of the depth of knowledge learners acquire [14]. These perspectives challenge a field interested in promoting emancipatory approaches that develop self-actualized learners as globalized citizens able to consider and deconstruct the systems of power that promote unsustainable practices [15]. These qualities rely on a deep, tacit understanding of the challenge and needed responses, of which competence acquisition's ability to provide has been questioned [14].

As the conversation regarding sustainability competencies has grown, their use has been proposed and developed by numerous authors in recent years [6,16-18]. Conducted literature reviews and workshop discussions have shown the desire of the field to explore the "critical role of defining key competencies and specific learning outcomes in order to successfully design and teach in academic programs" [18] (p. 204). Sterling et al. conducted a critical inquiry into the role and state of competence potential for ESD, and suggested that their role could be critical as a vehicle for pedagogical change by developing transformative learning experiences and catalyzing institutional responses that promote values of sustainability education from a more emancipatory perspective [19].

This study also suggested that a systematic review by Wiek et al. played an important role in attempting to synthesize ongoing competence-related findings into a framework of five competencies designed to "benefit a range of institutional processes from designing and revising academic programs through teaching and learning evaluations" [18] (p. 204). These competence are articulated as Systems competence, Anticipatory competence, Normative competence, Strategic competence and Interpersonal competence [18].

While the framework remains incomplete, it is seen to provide a "sufficient and promising foundation from which to develop complimentary, more robust, detailed and contextualized competencies" [20] (p. 128). Despite numerous competence lists having been developed to articulate iterations or competencies for specific areas [17,21] or as a compliment to Wiek et al.'s framework [20], the Framework has been highly supported by a variety of scholars [16] despite its limitations. For educators, while the question of competencies continues to emerge regarding framing and definitions, a number of authors believe that this initial development highlights a critical and useful entry point for pedagogical design, as educators consider what the knowledge and skill profiles of students expected to be future problem solvers, change agents and transition managers, require $[6,16,19,20]$.

Despite the discussion around competencies continuing to evolve, challenges remain, with uncertainties emerging in the relationship between pedagogies, competence acquisition [17] and assessment [13]. The continued vigor regarding research for competencies-based learning for ESD has highlighted the field's desire to develop robust competence guidelines that contribute to the construction and development of current and future ESD programs. This study aims to contribute this area of research by utilizing a case study to assess the impact of an international study abroad program and pedagogy, the Engineers without Borders Design Summit, on the acquisition of sustainability competence in its program participants as they study human-centered design in real-world settings.

\section{Methods}

In order to determine if the Design Summit program promotes the acquisition of sustainability competence within its students, an instrumental case study approach [22] was undertaken incorporating two stages of research design:

1. Mapping the presence of sustainability competencies (using their defined concepts and methodologies) in program content;

2. Analyzing participant feedback forms to identify statements supporting the acquisition of competence (concepts and methodologies) during the program. 


\subsection{Case Study: The Humanitarian Design Summit Program}

The Engineers without Borders Humanitarian Design Summit program is a 14-day immersive international study program that operates in six countries in the Indo-Pacific. The program participants have numbered 1200 first to fifth year Australian university students since 2015, conducted in partnership with 28 in country community organizations. Each individual program has between $28-48$ students, hosted by $6-9$ facilitators. The Summit program utilizes one week in the country teaching content and theory, and one week of immersive practice with local communities. Here, students are expected to identify and conceive a "potential" design solution to a challenge faced by the community.

The program outcomes aim to provide participant learning experience in:

- Humanitarian engineering skills and insights;

- Appropriate technology best-practice;

- Designing in resource constrained environments;

- Working with community and clients on needs analysis and problem definition;

- Evaluating solutions including maintenance, materials and cost;

- Rapid prototyping and development;

- Client engagement and communication;

- Cross-cultural engagement, teamwork and project management [23].

The program pedagogy has been designed by Engineers without Borders, utilizing content and theory from a number of sources. The topics taught include international development theory, human-centered design process [24], sustainable development, communication and cultural sensitivity knowledge and skills. A Design Summit Toolkit provides a pedagogical framework for program content, lesson plans, learning outcomes and facilitation techniques [25]. This program content is analyzed in Stage 1 of the research design in line with the Sustainability Competencies Framework (Table 1) and results are displayed in Table 2.

Table 1. Sustainability Competencies Framework [18].

\begin{tabular}{|c|c|c|}
\hline Competence & Knowledge/Concepts & Method/Skill \\
\hline Systems & $\begin{array}{c}\text { Ability to understand how differing } \\
\text { systems interact across differing domains } \\
\text { and scales. }\end{array}$ & $\begin{array}{l}\text { Ability to generate and interpret results } \\
\text { showing how different systems interact } \\
\text { across different domains and scales. }\end{array}$ \\
\hline Anticipatory & $\begin{array}{l}\text { Ability to understand differing future } \\
\text { visions, states and impacts related to } \\
\text { sustainability. }\end{array}$ & $\begin{array}{l}\text { Ability to generate and interpret results } \\
\text { showing differing future visions, states } \\
\text { and impacts related to sustainability. }\end{array}$ \\
\hline Normative & $\begin{array}{l}\text { Ability to understand the } \\
\text { (un)sustainability of current/future states } \\
\text { and required values, ethics, principles, } \\
\text { lifestyles etc. }\end{array}$ & $\begin{array}{l}\text { Ability to generate and interpret results } \\
\text { about the (un)sustainability of } \\
\text { current/future states and required values, } \\
\text { ethics, principles, lifestyles etc. }\end{array}$ \\
\hline Strategic & $\begin{array}{l}\text { Ability to understand the design and } \\
\text { implementation of intervention and } \\
\text { transformative governance strategies for } \\
\text { sustainability. }\end{array}$ & $\begin{array}{l}\text { Ability to generate change and evaluate } \\
\text { the design and implementation of } \\
\text { interventions and transformative } \\
\text { governance strategies for sustainability. }\end{array}$ \\
\hline Interpersonal & $\begin{array}{l}\text { Ability to understand collaborative and } \\
\text { participatory sustainability research and } \\
\text { problem-solving. }\end{array}$ & $\begin{array}{c}\text { Ability to facilitate collaborative and } \\
\text { participatory sustainability research and } \\
\text { problem-solving. }\end{array}$ \\
\hline
\end{tabular}

Adapted from [26]. 
Table 2. Presence of competence within content.

\begin{tabular}{|c|c|c|}
\hline Session Content & $\begin{array}{c}\text { Concept and Methodology } \\
\text { Present }\end{array}$ & Competence (s) Outcome \\
\hline Introduction into Culture (p. 34) & $\begin{array}{c}\text { 1B, 1C, 1E, 1G, 2A, 2D, 3A, 3C, 3F, } \\
4 \mathrm{~A}, 4 \mathrm{H}, 4 \mathrm{I}, 5 \mathrm{~A}, 5 \mathrm{~F}\end{array}$ & $\begin{array}{l}\text { Systems anticipatory normative } \\
\text { strategic interpersonal }\end{array}$ \\
\hline Development 101 (p. 35) & $\begin{array}{c}1 \mathrm{~B}, 1 \mathrm{E}, 1 \mathrm{D}, 2 \mathrm{~A}, 2 \mathrm{C}, 2 \mathrm{E}, 2 \mathrm{D}, 3 \mathrm{C}, 3 \mathrm{~F} \\
4 \mathrm{~B}, 4 \mathrm{E}, 4 \mathrm{I}\end{array}$ & $\begin{array}{c}\text { Systems anticipatory normative } \\
\text { strategic }\end{array}$ \\
\hline Language Lesson (p. 38) & $1 \mathrm{E}, 1 \mathrm{I}, 1 \mathrm{~A}, 5 \mathrm{E}$ & Systems Interpersonal \\
\hline $\begin{array}{c}\text { Communication and Cultural } \\
\text { Sensitivity (p. 39) }\end{array}$ & $1 \mathrm{E}, 3 \mathrm{~K}, 4 \mathrm{H}, 5 \mathrm{~A}$ & $\begin{array}{l}\text { Systems normative strategic } \\
\text { interpersonal }\end{array}$ \\
\hline $\begin{array}{c}\text { Appropriate Technology \& } \\
\text { Human Centred Design (p. 40) }\end{array}$ & $\begin{array}{c}1 \mathrm{C}, 1 \mathrm{E}, 1 \mathrm{I}, 2 \mathrm{E}, 3 \mathrm{C}, 3 \mathrm{~F}, 3 \mathrm{~K}, 4 \mathrm{D}, 4 \mathrm{~F} \\
4 \mathrm{~L}, 5 \mathrm{~A}\end{array}$ & $\begin{array}{l}\text { Systems anticipatory normative } \\
\text { strategic interpersonal }\end{array}$ \\
\hline $\begin{array}{l}\text { Design 1: Human Centred Design } \\
\text { (p. 41) }\end{array}$ & $\begin{array}{c}\text { 1B, 1I, 2J, 3F, 3J, 4B, 4H, 4K, 4M, } \\
5 \mathrm{~A}, 5 \mathrm{~B}, 5 \mathrm{E}, 5 \mathrm{~F}, 5 \mathrm{G}\end{array}$ & $\begin{array}{l}\text { Systems anticipatory normative } \\
\text { strategic interpersonal }\end{array}$ \\
\hline
\end{tabular}

\subsection{Sustainability Competencies Framework}

This study has utilized the conceptual competence framework developed by Wiek et al., as it provides "a comprehensive framework of five key competencies emphasized by sustainability experts in academic programs in eight universities" [26] (p. 6) and displayed in Table 1. Furthermore, the construction of the framework stemmed from a systematic literature review that considered the relevant literature and created competence definitions using "representative concepts, methodologies, and peer-reviewed "classics" [18] to construct robust explanations of each of the five competencies. Although the framework does not offer a specific definition of what constitutes concepts or methodologies, this study sees them as the individual ideas and components that contribute to building and defining each competence boundary. A sixth competence, developed later as "Integrated Competence," [16], was excluded from the study due to the lack of a distinct and robust categorisation of the concept and methodologies shared by the other competencies.

\subsection{The Question of Competence Acquisition}

Due to the practice of assessing student sustainability competencies being in its infancy, educators "lack the means to effectively assess whether they are successfully educating sustainability professionals through their courses and programs" [6] (p. 2). Thus, this study utilizes a form of regular course work assessment, in which student coursework is examined to demonstrate competence acquisition as educators search for evidence of competencies within student learning. Because of this, the study argues that competencies are defined as acquired by the subjective description of them within the student self-assessment [6] of the feedback forms. Thus, we highlight the acquisition of sustainability competence through self-described student learning, terming them as "mentions" and using these "mentions" as evidence of competence acquisition. This study acknowledges the challenge of assessing acquisition within the field and aims to offer a method that provides development while acknowledging the need for an exploration of robust assessment and measurement mechanisms.

\subsection{Coding the Competencies}

Each competence was categorised from one to five (Systems $=1$, Anticipatory $=2$, Normative $=3$, Strategic $=4$, Interpersonal $=5$ ). The concepts and methodologies that construct each competence were then categorised alphabetically. When examples of the concept or methodology were seen in the content or mentioned in feedback forms, they were identified and marked by their distinct value. The competence coding structure is portrayed in Appendix A.

\subsection{Stage 1: Mapping Presence of Competencies with Program Pedagogy}

Using the Summit Toolkit and competence coding structure, the program content was then analyzed to examine the presence of competence concepts and methodologies within the pedagogical 
content. The program content was defined from the Design Summit Toolkit, a facilitator manual that maps all lesson plans of the program [25]. These lesson plan outlines were then mapped against the competence list in direct relation to the coding structure of Wiek's competencies framework [18] and all competencies present within a lesson plan were marked. For example, "Design 1," a session that introduces and teaches Human Centered Design is categorized 4C, as it involves teaching "Strategies, action programs, (systemic) intervention, transformative governance", and 5G for "Teamwork methods" among others, as it involves groupwork, highlighting the presences of "strategic and interpersonal competence".

\subsection{Stage 2: Using Participant Feedback to Highlight Competence Acquisition}

The Summit Program collects feedback forms for all students at the conclusion of each program. This study used a random sampling method in which participant data were used to map competence learning within the student participants. To date, 1200 students have attended the program in total. The research used 137 students, randomly selected from four complete Summit programs, and analysed feedback forms, meaning an $11.42 \%$ sample size. Each program was categorised by country/month/year/participant prefix to identify and map specific responses, e.g., Nep0218_05 (Nepal, February 2018, Participant 5).

\subsection{Coding Structure}

Data were collected and then analysed using the coding structure (Appendix A) developed from Wiek et al.'s (2011) competency framework to see if the presence of competence acquisition was demonstrated within student feedback. This was highlighted by participants in the form of statements, quotes or articulation of learning that related to the competencies as determined by their concepts or methodology. Statements matching the description of a competence through a concept or methodology were then marked within the feedback and noted as evidence of that concept or methodology, and thus that competence.

For example, feedback that stated:

"Interacting with different cultures was a significant part of my learning" would be noted down as $1 \mathrm{E}$ highlighting Systems competence, identified through the engagement with the concept of "People and Social Systems: values, preferences, needs, perceptions, (collective) actions, decisions, power, tactics, politics, law, institutions etc." Likewise, stating "the ability to empathise and centralise working with people" was noted as 5A for "Functions, Types and Dynamics of collaboration" highlighting Interpersonal competence. Each feedback form was entered into an Excel spreadsheet to map the competencies, concepts and methodologies that were occurring within the feedback. If individual students mentioned the same competence, concept or methodology multiple times within their feedback form, these were noted but counted as a single mention and categorized as such. Statements mentioning a competence concept or methodology were then collated as evidence of competence acquisition.

\section{Results}

\subsection{Competence Presence in Program Content}

The study began by comparing lesson plans of the program with the competence framework. This analysis highlighted that the program content utilizes and teaches a number of concepts and methodologies defined in the competencies. Below, these concepts and methodologies are mapped to the six main program sessions, as defined by the program toolkit. This analysis found that most sessions engage multiple competences.

In checking the content for competencies, results suggest the presence of all competencies within the taught program content. For example, the "Development 101" session [25] involves a one-hour interactive workshop that highlights the complex and interrelated nature of international and sustainable development. In doing so, it presents and asks participants to reflect and discuss the "(Un)sustainability 
of current systems," (developing Normative competence), "Possible future scenarios" (Anticipatory competence) and "Concepts of justice, fairness, responsibility and safety", over large time-scales and domains (Normative competence). The "Communication and Cultural Sensitivity" workshop [25] asks students to consider how to interact with local communities, as it utilizes conceptual discussions of "People and social systems: values, preferences, needs, perceptions, (collective) actions, decisions, power, tactics, politics and institutions" (Systems competence) and "Functions, types and dynamics of collaboration", as students engage with community (Interpersonal competence) and the design of "Participatory anticipatory processes" (Anticipatory competence).

The "Design 1" [25] (p. 39) workshop introduces and teaches Human-Centered Design (HCD) processes as a tool for community development. HCD is a concept built from numerous processes thus spanning a number of the competencies. For example, HCD utilizes both "Participatory methods," and "Planning methodologies" and also considers "Ethical concepts", thus highlighting student development of numerous competencies (Interpersonal, Strategic and Normative competencies) as they engage and practice with the concept.

Therefore, by examining the program pedagogy in alignment with the competencies framework, we can see the presence of the all five competencies of the framework within the content taught by the program and shown in Table 2.

\subsection{Uncovering Significant Evidence of Competence Acquisition in Student Learning}

Measuring student learning by analyzing feedback forms showed that there were 450 individual statements aligning with a specific competence concepts or methodologies by 137 students, indicating evidence of competence acquisition. A breakdown of each competence from most- to least-mentioned shows Interpersonal competence (166 mentions-37\%), Strategic competence (124-27\%) and Systems competence (85-19\%) as the main areas of competence acquisition, while Normative (57-13\%) and Anticipatory (18-4\%) showed less acquisition.

In looking at the prevalence of specific concepts or methodologies (Figure 1), "People and Social Systems" (Systems competence) and "Functions, types and dynamics of collaboration" (Interpersonal competence) were the most prevalent (49 each), closely followed by "Methods to Support Learning and Reflexivity" (48 mentions). "Teamwork Methods" (Interpersonal) and "Strategies Actions, programs" (Strategic competence) were also highly mentioned (44 and 43). A number of the concepts and methods were not mentioned at all. These included "Risk Analysis" (Normative competence), "Transition Support Methodologies" (Strategic competence) and "Scenario Methodology" (Anticipatory competence). A table of concepts and methodologies by mentions is detailed below in Figure 1.

\subsection{Two Emerging Results-Developed Self-Awareness and Improved Presentation Skills}

Two significant themes emerging from the program data were not categorizable within the competence framework. These emerging themes are described as:

1. Developing self-awareness and purpose;

2. Improved communication skills. 


\section{Competence Mentions}

Functions, types and dynamics of collaboration...

People and Social Systems: values, preferences,...

Methods to support learning and reflexivity

Teamwork Methods

Strategies, action programs, (systemic) intervention,...

Concepts of solidarity and ethnocentrism

Participatory methods (e.g negotiation methods,... Strengths, weaknesses, success and failures in teams

Success factors, viability, feasibility, effectiveness,... Limit of cooperation and leadership Across multiple scales: local to global, Social learning

Across /multiple/coupled domains (society,...

Participatory Methods, including negotiation,...

Concepts of justice, fairness, responsibility, safety,...

Participatory systems approaches (e.g participatory...

Ethical Concepts

Participatory anticipatory approaches (e.g Delphi,...

(Un-)sustainability of current or future states

Backcasting and envisioning methods

Concepts of uncertainty and epistemic status,...

Planning methodologies

Obstacles (resistance, reluctance, path dependency,...

Social Movements

Envisioning Methods (e.g backcasting)

Sustainability efficiency analysis

Multi-criteria assessment methods (normative.. Sustainability principles, goals, targets, thresholds..

Concepts of time including temporal phases (past,...

Qualitative and quantitative modeling

Feedback loops, complex cause and effect chains,...

Intentionality

Concept of risk, harm, damage,

Concepts of risk, intergenerational equity, precaution

Concepts of consistency and plausibility of future... I
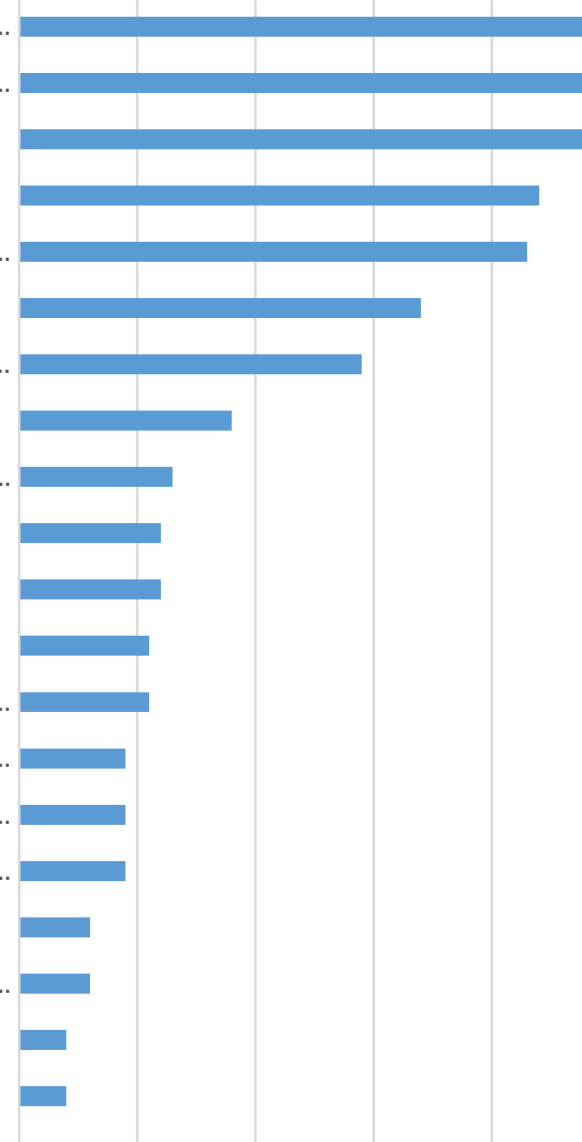


\subsubsection{Developed Self-Awareness and Purpose}

Many statements (56) reflected learning around developing self-awareness and personal learning. These statements included that the program "gives me inspiration and motivation to do what I do" (Nep0218_11) and "I hope to leave the summit slightly more aware of the outside world, with more compassion and understanding. I hope I will not settle into my old routines at home and try to be more proactive with how I spend my time" (Nep0218_16). While these statements do not reflect a single competence, concept or methodology, they suggest that a significant theme has occurred within a number of students. Further descriptions highlighted the sense of a unique personal change within students, including statements such as "the summit has given me confidence to question the assumptions I have as well as to be more curious" (Nep0218_10), "was totally eye opening, it made me question what was important in my life" (Nep0217_29), "a humbling and grounding experience... I have a broader view on life" (Nep0218_31) and "a life changing experience that put everything into perspective" (Mal1807_05). These quotes reflect the presence of deep personal learning that does not relate to the current competencies framework, yet seems integral to the experience of the program and learning of the students and cannot currently be represented within the current model proposed by Wiek et al. [18].

\subsubsection{Developed Communication Skills}

The second emerging theme was improving communication skill in the form of confidence presenting and communicating of ideas. This theme consistently emerged as a significant outcome with student learning, occurring within 42 mentions by students. This rated higher than significant competencies such as "participatory methods" (29) and "social learning" (11), and highlighted the important notion that students felt they acquired increased communication competencies during the program, which developed from the process of presenting their work to diverse audiences and within teamwork. Despite this, the competencies framework in its current state does not identify a strong presentation or communication specific concept or methodology within its definitions, despite its requirement as an integral component of numerous competencies, specifically Interpersonal. This means that improvement of such skills is a significant educational outcome that currently lacks a distinct place of categorization within the competence framework.

\subsection{High Competence Presence and Low "Sustainability" Mentions}

An interesting outcome of the data was that, within the 450 mentions of the competencies by students in their reflection on learning, there were only twelve explicit mentions of "sustainability" and two of "climate change". This highlights that, while students are often undergoing educational activities that help to acquire "sustainability" competencies, they are perhaps not connecting these with sustainability as a concept itself. This point will be explored more within the discussion section.

\section{Discussion}

The findings of this study indicate that students attending the Design Summit program do acquire sustainability competencies as defined by the sustainability competencies framework presented by Wiek et al. [18]. This is evidenced by the presence of the competencies in pedagogical content, and significantly in the number of concept and methodology mentions within student feedback. The students displayed various amounts of learning across 34 of the competence framework's 52 concepts and methodologies, with a focus on the Interpersonal and Strategic competencies. Interestingly, despite evidence of "sustainability" competence acquisitions, only twelve (of 450) explicit mentions of "sustainability" or "climate change" occurred in the data. Thus, these findings uncovered a number of interesting questions and outcomes for Education for Sustainable Development (ESD) pedagogy and competence-based sustainability learning. This is discussed below. 


\subsection{Implementing Processes Can Result in Efficient Multiple Competence Acquisition}

The results reflect that utilising Human-Centered Design (HCD) as the main theoretical content and learning outcome of the program promoted learning across a number of the competencies. As HCD is both a theory to learn and a process to implement, students can acquire competence across a range of the concepts and methodologies, as their participation engages both theoretical understanding and practical implementation. For example, by firstly teaching HCD as a theoretical concept to be understood, students engaged the concept as a "Strategies, actions programs (systemic intervention), transformative governance" (43 mentions), thus developing their Strategic competence, while the act of students specifically engaging with community as part of practical HCD implementation showed learning from the perspective of "Functions, types and dynamics of collaboration" (49 mentions), thus developing their Interpersonal competence. Furthermore, feedback that articulated increased student knowledge of the community from the practical implementation of HCD processes highlighted learning from "People and social systems" (49 mentions) perspective, developing their Systems competence. The implication of this finding is that designing a pedagogy that engages both theoretical and practical learning of a single piece of content may allow for a greater spread of competence acquistion. This supports the general idea that pedagogy utilsing both theory and practice together can be an effective tool for ESD educators in relation to sustainability competence acquisition [27]. This, in turn, supports research that advocates for problem-based and real-world pedagogies as efficient modes of sustainability learning and suggests a likely proficiency of those pedagogies for competence acquisition [26]. Despite this, methods that promote real-world and problem-based learning have so been underutilised as pedagogies to date [28], despite their emergence within ESD.

\subsection{Can Students Become Competence Literate and Remain Context-Lacking?}

An interesting result of the study was the lack of explicit mentions of sustainability or climate change (14 mentions) despite the evidence ( 450 mentions) of competence concepts and methodologies. This raises the question of dissonance between acquired competencies and individual understanding of their role for sustainability. While sustainability is not an explicit part of the taught content, it remains an underlying component and vocal consideration within the program. However, these results indicate that if competence-based learning environments are not contextualized with sustainability understanding, it seems that competencies can be acquired but remain uncoupled to "sustainability". For example, students may be able to display systems competence by constructing community asset maps [25], but this activity does not guarantee sustainability understanding or outcomes unless the action of mapping is consciously framed by and done for the purpose of sustainability. The latter, in turn, requires that students understand what sustainability is. Without such understanding, the competencies fail to function for systematic sustainable development. This point remains key to ongoing competence learning, as it suggests that ESD pedagogies must ensure they include or connect learning to a contextualized sustainability understanding and promote the transmission of the competencies within this sustainability understanding. That is, that the competencies are employed as tools to implement sustainability, not just as tools.

\subsection{The Need to Contextualize the Competencies for "Strategic" Sustainability Outcomes}

As discussed, the prevalence of competence acquisition evidenced in the data, contrasted by the lack of explicit "sustainability" reflections by students, suggests the need for competence learning to occur within explicit contextualization of sustainability. How can this occur? A number of pedagogical possibilities for this are discussed below.

\subsection{Using Sustainability Principles to Frame Competence Acquisition}

One suggestion is for educators is to frame competence learning from a scientific perspective that provides a robust understanding of socio-ecological sustainability that can be used as boundary 
conditions for sustainability contextualization. While the use of diverse knowledge sets and epistemological stances are important in contributing to sustainable transitions, leadership that promotes scientifically verifiable sustainable development [29] plays an integral role and provides a shared international language. The Sustainability Principles of the Framework for Strategic Sustainable Development (FSSD) [3] provide a scientific, peer-reviewed understanding of the boundary conditions of sustainability. These principles, which provide three ecological and five social definitions of sustainability (Table 3), aim to be necessary and sufficient for sustainability. That is, they define the exact boundary within which society complies with or violates sustainability. They also aim to be general, in order to facilitate cross-disciplinary and cross-sector collaboration, concrete, to actually guide innovation for sustainability, and non-overlapping, to facilitate the comprehension and development of indicators [3] and allow individuals acting towards sustainability to know whether they are contributing to the challenge of sustainability or helping to overcome it by aligning their work within these boundaries. The principles are stated below, followed by a discussion of how they can be used in learning environments to facilitate competence acquisition (see Figure 1).

Table 3. Definition of ecologically and socially sustainable societies [3].

\begin{tabular}{|c|c|}
\hline Ecological & Social \\
\hline $\begin{array}{l}\text { "In an ecologically sustainable society, nature is not } \\
\text { subject to systematically increasing. }\end{array}$ & $\begin{array}{c}\text { In a socially sustainable society, people are not subject } \\
\text { to structural obstacles to ... }\end{array}$ \\
\hline $\begin{array}{c}\text { SP1 . . concentrations of substances extracted from } \\
\text { the Earth's crust. SP2 ... concentrations of substances } \\
\text { produced by society. SP3 ... degradation by } \\
\text { physical means. }\end{array}$ & $\begin{array}{l}\text { SP } 4 \ldots \text { health. SP5 } \ldots \text { influence. } \\
\text { SP6 .. competence. SP7 ... impartiality. } \\
\text { SP8 ... meaning-making". }\end{array}$ \\
\hline
\end{tabular}

Using these sustainability principles to frame learning, educators can create a sustainability-contextualized container in which competencies are acquired. This would allow students to move from "competence literate and context lacking" to "competence and context literate" by developing their understanding of sustainability, and thus how the competencies can be implemented to achieve it. Furthermore, the study in Figure 2 aims to illustrate that acquiring competencies with a scientific understanding of sustainability provided by the principles can help to guide implementation of the competencies in a unified direction. By implementing actions using the same understanding of sustainability, practitioners can utilize numerous competencies or knowledge flexibly while remaining coordinated towards sustainability, as long as initiatives operate within the boundaries the principles provide [3]. Simply put, if competencies are acquired without a robust understanding of sustainability, their implementation may result in competence implementations that works in localized contexts (1) and (2) does not contribute towards a globally sustainability society. If all implementation of the competencies is carried out within the framing of the principles, then acts utilizing the principles and competencies operate towards a coherent and unified goal. Thus, incorporating the principles of the FSSD into learning environments in which competencies are acquired has the potential to both contextualize initial competence learning for sustainability and align future implementation of the competencies in a long-term manner that promotes strategic sustainable development (3). 


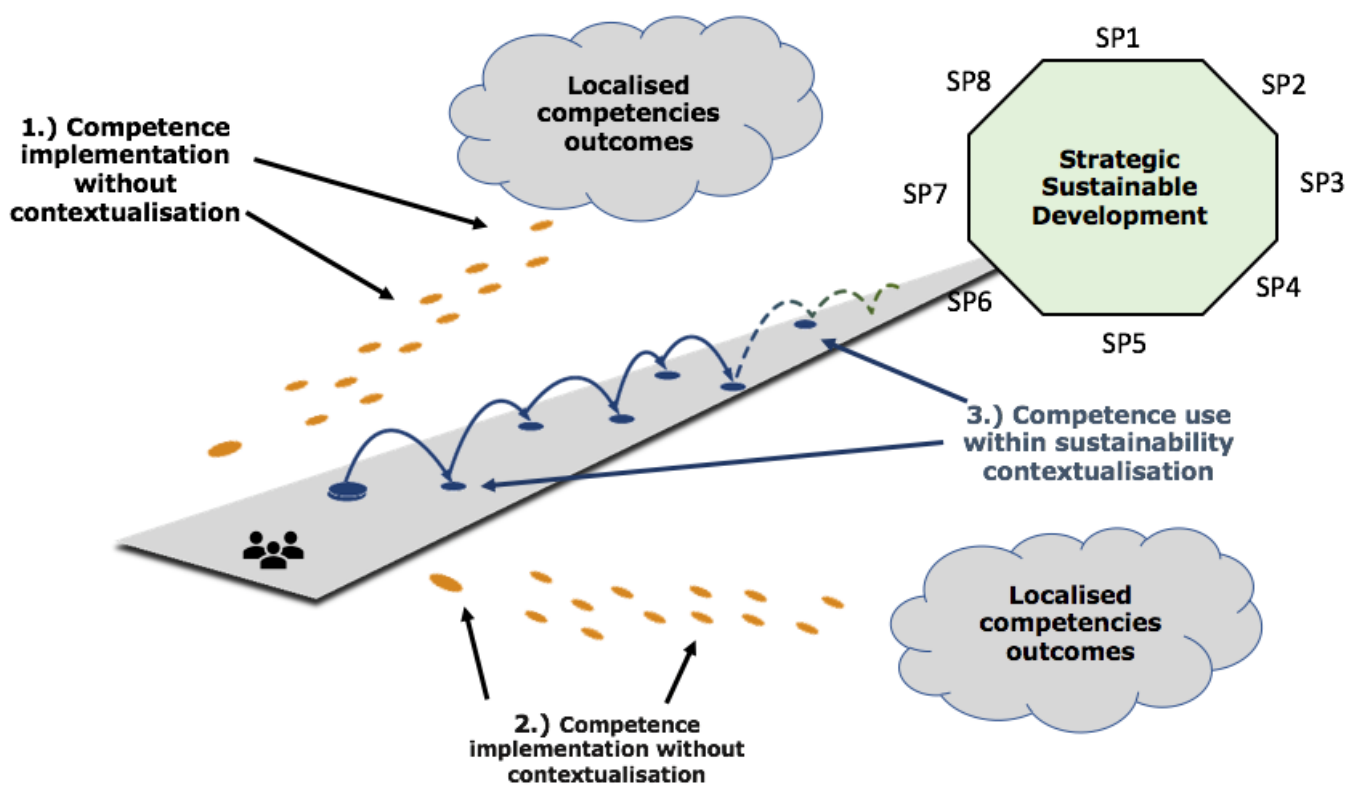

Figure 2. Scenarios of competence implementation for sustainability outcomes (1) competence implementation without sustainability contextualization = independent localized outcomes, (2) competence implementation without sustainability contextualization = independent localized outcomes and (3) competence implementation within robust sustainability principles as boundary conditions $=$ unified sustainable development outcomes.

While the principles provide a robust understanding of sustainability, educators must also ensure that students are motivated to implement their acquired competencies for that purpose. Essentially, this means also inspiring students to act towards sustainability as a vocation. While a common mental model (the principles) may create inspiration in itself, the experiential aspects of study abroad pedagogies may provide an even more emotional, personal contextualization of sustainability to serve as further inspiration. We discuss those possibilities below.

\subsection{The Facilitator as a "Sustainability" Guide}

If educators aim to further contextualise competence learning within sustainability, the experience of study abroad pedagogies holds significant potential for doing so if the unique experience provided by the program is framed from a perspective of sustainability. Here, the role and power of the facilitator or teacher's epistemology as the lens through which students experience and contextualise their learning becomes integral. Interestingly, the Summit program pedagogy currently operates from a "design" epistemology and framing, promoting the notion that development can be addressed through design solutions. This framing is likely the reason for the 63 mentions of "design" terminology within the data and, of the mentions of "sustainability" (12) or "climate change" (2) found within the data, nine were made by students led by a facilitator who primarily worked as a sustainability lecturer. These students reported statements such as "I would definitely like to research more on development and sustainability. The summit increased my interest in those areas a lot." (IND1801_07) and "I have lots of reading and research to do about Human Centered Design, sustainability, leadership and development." (IND1801_01) and an interest in "learning more about career options around sustainability" (IND1801_04). This highlights how impactful the role and perspective of the "teacher" is, a notion supported by Lidar et al., who argues that "what students are supposed to observe is something that they have to learn, and the teacher is of decisive importance for this learning" [30] (p. 160). From this perspective, as educators design pedagogy based on competence acquisition, they should consider how the epistemology and language of the learning environment, as influenced by the teacher or program, influences student 
understanding If the competencies are not continually framed as means for sustainability problem solving or within sustainability perspectives, then students will not be motivated to use them as such.

\subsection{Creating Student Sustainability Values by Experiencing "Unsustainability"}

A second study abroad contextualization and motivational tool considers the impact of student experience with "unsustainability" during the program. Engaging with the community around issues of climate change, drought and poverty remains a common experience. Comments including "the opportunity to gain a more sophisticated insight into poverty and the issues that feed into poverty" (Nep0218_05) and undergoing experiences that lead to "challenging our perceptions about poverty" (Nep0218_04) highlight sustainability-related questions raised by students as a result of their experience with study abroad. Furthermore, these experiences led to individuals "dealing with being outside of (my) comfort zone in unfamiliar environments" (Nep0218_14). By experiencing unsustainability and communities affected by it, students may have an experience suggestive of the "disorientating dilemma" of Transformational Learning [21] processes, one that results in a shift in the student's frame of reference and worldview [22], resulting in a greater awareness of sustainability issues and increased motivation to act.

By considering the visceral experience of students with unsustainability on study abroad programs, educators can consider how the experience can intervene in student worldviews and serve to shift mental models in students towards a holistic, personal understanding of sustainability. The high indication of "developed self-awareness" that emerged from the data (56 mentions) highlights that a significant experience is occurring within the students. Perhaps harnessing this experience and the disorientation of unsustainability in study abroad students can encourage the development of a robust set of sustainability values that scaffold their future actions and leadership. Wiek et al. suggest the need for diverse and rich cross cultural and real-world learning experiences that are critical to developing competencies [21] and this study supports that claim, showing that the acquisition of competencies occurs even in a program not explicitly teaching them. Glasser also suggests that the competencies framework could evolve into a living typology of skills rooted in values of sustainability, commitment and understanding, based on (1) commitment to the common good, (2) care and interest for others, and (3) care for self [31]. Research supports the notion that experiential learning has the ability to empower, engage and motivate students [32], while Sipos argues for a "Head, Heart, Hands" approach to learning, in which action learning encourages students to questions their assumptions and beliefs in a way that promotes personal paradigm shifts [12]. These suggestions highlight the integral nature of individuals' relationships with sustainability as a result of their active participation with it. If they are to act on and successfully implement acquired competencies towards sustainability, then study abroad programs may provide an effective pedagogical model to achieve that.

\subsection{Three Outcomes to Activate Sustainability Competencies}

Based on this study, we suggest that educators consider three elements to situate competence acquisition within sustainability, as shown in Figure 3. They are (A) using science-based, unifying sustainability principles to define sustainability, (B) using sustainability epistemic teachers as "guides" and $(C)$ using the personal student experience with unsustainability to encourage and motivate sustainability awareness and action. These outcomes have implications for ESD pedagogies regardless of their nature, as learning environments can implement and consider these variables in their design. 


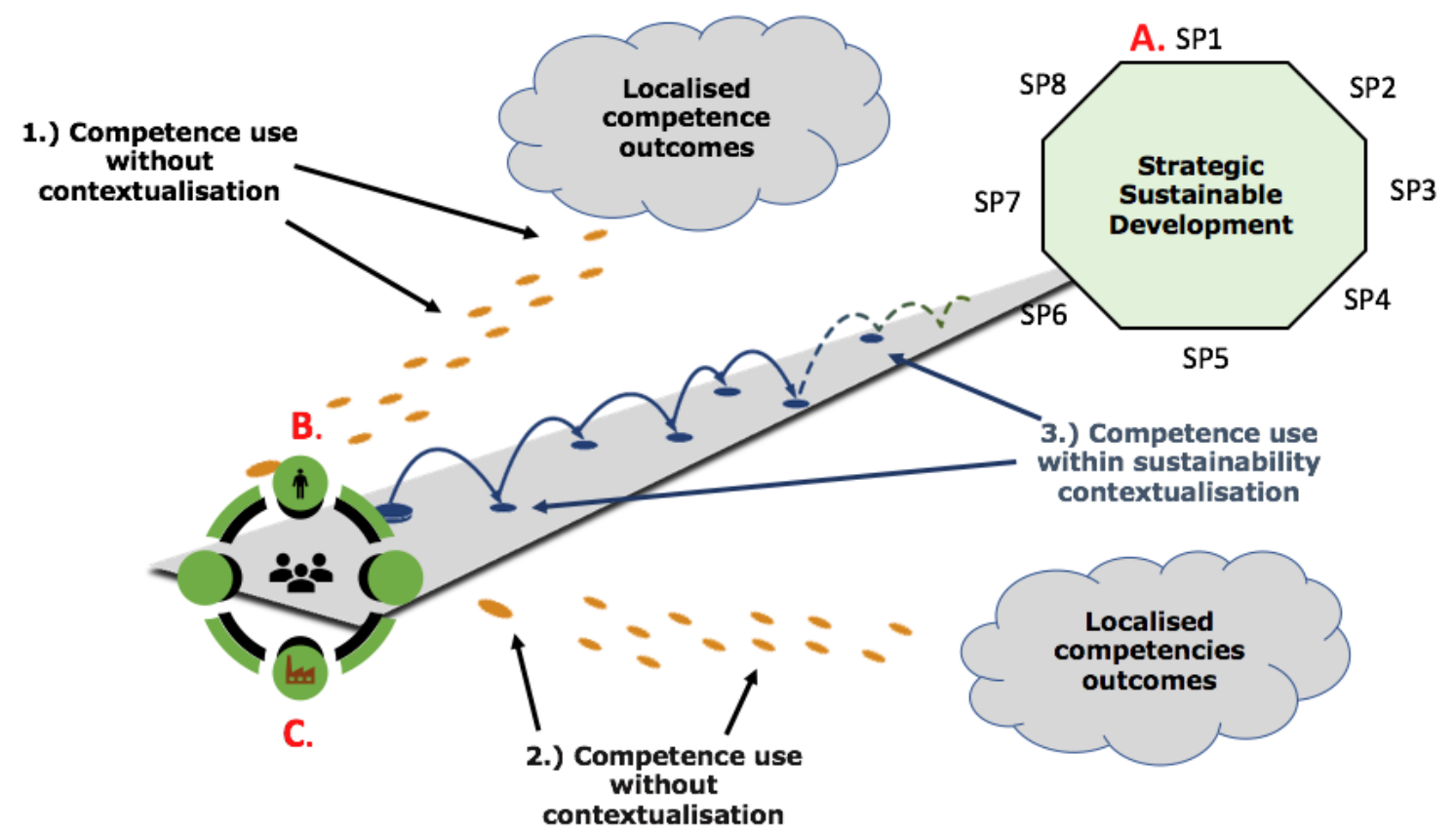

Figure 3. Learning Environment utilizing the three contextualisations (A) sustainability principles to situate competence implementation in strategic sustainable development, (B) use of sustainability epistemic teacher as "guide", and (C) facilitating student experience with unsustainability.

\section{8. "Activated" Competencies to Promote Strategic Sustainability Outcomes}

The sustainability principles unify and direct future work. Sustainability epistemic teachers and the development of the student's personal relationship with unsustainability promote understanding and motivation to act towards sustainability. Combined, this study suggests that these elements make the competencies "activated" towards sustainability. We argue that without these considerations, the competencies can be acquired but not efficiently or coherently used to move society towards sustainability.

\subsection{Limitations and Future Research}

The study has a number of limitations. Firstly, the data collected were not specifically designed to test for the acquisition of competencies as defined by Wiek et al., As discussed earlier, the study adopts a "regular coursework" assessment model that seeks to discover learning as a result of the program by retrospectively looking for engagement with competencies [6]. The subjective nature of the student commentary implies a weakness, as the study cannot definitely state that the competencies are being acquired. This is a general limitation for similar studies, one that has provoked ongoing considerations of how to assess sustainability learning or acquisition of sustainability competencies [6] as there remains a lack of empirical evidence as to how certain pedagogies result in successful acquisition of sustainability competencies. This study sufferers from those challenges, as well as the difficulty of developing an assessment tool "as an afterthought" [6] (p. 12). Despite this, investigating a program that "assumed" sustainability learning implicitly, despite lacking a model to comprehensively assess this, remains worthwhile and contributes both to the development of the pedagogy as a tool for sustainability learning and the ongoing discussion of competence research within ESD through its finding and suggestions.

Finally, the study has a number of challenges from situating competencies when coding student responses. It often becomes difficult to determine or allocate which competencies are being described in the data and when. For example, was Human Centred Design process, which was prevalent in the data, to be treated as a "Participatory Systems Approach" in which it would be describe Systems competence, or was it "Strategies, action program (systemic intervention)" or a "Planning Methodology" in which case 
it would be described as a "Strategic competence"? Likewise, empathy, which was mentioned by a high number of students, could be allocated as an "Ethical concept" (Normative competence), "Social learning" (Strategic competence) or "Concept of solidarity and ethnocentrism" (Interpersonal competence). In this case, the description was coded in line with the context of the statement as best as possible.

Discussing the difficulty of differentiating between competency allocation is not meant to be a criticism of the competencies framework and supports the notion that assessing students "assignments are rarely well suited for assessing competence" [6] (p. 2). It also highlights the interconnected and overlapping nature of the competencies. These findings support the notion that, currently, the competencies work as guides that can be used in the pedagogical design of learning environments [31], while the discussion of pedagogies and competence relationship develops.

\section{Conclusions}

This study aimed to investigate whether the Design Summit program results in the acquisition of sustainability competencies within its students. The study resulted in the belief that students acquire competencies as defined by Wiek et al. [18], as a result of the program, but that competencies' acquisition and competencies' acquisition for sustainability require further consideration. Firstly, for the competencies to fulfil their potential as leverage points for sustainability, they need to be situated within "sustainability" knowledge rather than just as process tools. Secondly, educators should consider the role of a sustainability epistemic teacher as a guide, to further contextualise competence learning, and student experience with "unsustainability" may play a role in further contextualisation and, importantly, the motivation of students to act towards sustainability as they develop a personal value set regarding sustainability.

Funding: This research received no external funding.

Acknowledgments: Acknowledgements to Engineers without Borders Australia, for providing access to the data collected on behalf of the program especially Bianca Anderson. Thanks also to Göran Broman, Merlina Missimer, Edith Callaghan, Jayne Bryant, Julius Piwowar and a number of reviewers for their wise feedback and advice which strengthened this paper immensely.

Conflicts of Interest: "The authors declare no conflict of interest and the funders had no role in the design of the study; in the collection, analyses, or interpretation of data; in the writing of the manuscript, or in the decision to publish the results".

\section{Appendix A}

Table A1. Competence Coding Structures.

\begin{tabular}{|c|c|c|}
\hline COMPETENCE & CODES & COMPETENCY CONCEPTS AND METHODOLOGIES \\
\hline \multirow{11}{*}{ SYSTEMS } & & Concept \\
\hline & $1 \mathrm{~A}$ & Variable/indicators, subsystems, structures and functions \\
\hline & 1B & $\begin{array}{c}\text { Feedback loops, complex cause and effect chains, cascading } \\
\text { effects, tipping points, legacy, resilience, adaptation, } \\
\text { structuration, etc. }\end{array}$ \\
\hline & $1 C$ & Across multiple scales: local to global, \\
\hline & 1D & $\begin{array}{l}\text { Across /multiple/coupled domains (society, environment, } \\
\text { economy, technology, etc.) }\end{array}$ \\
\hline & $1 \mathrm{E}$ & $\begin{array}{l}\text { People and Social Systems: values, preferences, needs, } \\
\text { perceptions, (collective) actions, decisions, power, tactics, } \\
\text { politics, laws, institutions etc. }\end{array}$ \\
\hline & & Methodology \\
\hline & $1 \mathrm{~F}$ & Qualitative and quantitative modelling \\
\hline & $1 \mathrm{G}$ & Institutional, decision, governance, social systems analysis \\
\hline & $1 \mathrm{H}$ & Multi-methodologies ('Thick' description) \\
\hline & $1 \mathrm{I}$ & $\begin{array}{l}\text { Participatory systems approaches (e.g., participatory } \\
\text { modelling) }\end{array}$ \\
\hline
\end{tabular}


Table A1. Cont.

\begin{tabular}{|c|c|c|}
\hline COMPETENCE & CODES & COMPETENCY CONCEPTS AND METHODOLOGIES \\
\hline \multirow[t]{12}{*}{ ANTICIPATORY } & & Concept \\
\hline & $2 \mathrm{~A}$ & $\begin{array}{l}\text { Concepts of time including temporal phases (past, present, } \\
\text { future), term (short, long), states, continuity (dynamics, paths), } \\
\text { non-linearity }\end{array}$ \\
\hline & 2B & $\begin{array}{l}\text { Concepts of uncertainty and epistemic status, including } \\
\text { possibility, probability, desirability of future developments } \\
\text { (predictions, scenarios, visions) }\end{array}$ \\
\hline & $2 \mathrm{C}$ & Concepts of inertia, path dependency, non-interventions \\
\hline & $2 \mathrm{D}$ & $\begin{array}{c}\text { Concepts of consistency and plausibility of future } \\
\text { developments }\end{array}$ \\
\hline & $2 \mathrm{E}$ & Concepts of risk, intergenerational equity, precaution \\
\hline & & Methodologies \\
\hline & $2 \mathrm{~F}$ & Scenario Methodology \\
\hline & $2 \mathrm{G}$ & Forecasting from statistical and simulation models \\
\hline & $2 \mathrm{H}$ & Backcasting and envisioning methods \\
\hline & $2 \mathrm{I}$ & Multi-Methodologies \\
\hline & 2J & $\begin{array}{l}\text { Participatory anticipatory approaches (e.g., Delphi, Future } \\
\text { Workshop) }\end{array}$ \\
\hline \multirow[t]{13}{*}{ NORMATIVE } & & Concept \\
\hline & $3 \mathrm{~A}$ & (Un-)sustainability of current or future states \\
\hline & $3 B$ & $\begin{array}{c}\text { Sustainability principles, goals, targets, thresholds (tipping } \\
\text { points) }\end{array}$ \\
\hline & $3 \mathrm{C}$ & $\begin{array}{c}\text { Concepts of justice, fairness, responsibility, safety, happiness, } \\
\text { etc. }\end{array}$ \\
\hline & $3 \mathrm{D}$ & Concept of risk, harm, damage, \\
\hline & $3 \mathrm{E}$ & Concepts of reinforcing gains ('win win') and tradeoffs \\
\hline & $3 \mathrm{~F}$ & Ethical Concepts \\
\hline & & Methodologies \\
\hline & $3 G$ & $\begin{array}{c}\text { Multi-criteria assessment methods (normative component of } \\
\text { assessment methods, including Life-Cycle Assessment, } \\
\text { Multi-Attribute Utility Theory, etc.) }\end{array}$ \\
\hline & $3 \mathrm{H}$ & Risk analysis \\
\hline & $3 \mathrm{I}$ & Sustainability efficiency analysis \\
\hline & $3 \mathrm{~J}$ & Envisioning Methods (e.g., backcasting) \\
\hline & $3 \mathrm{~K}$ & $\begin{array}{c}\text { Participatory methods (e.g., negotiation methods, consensus, } \\
\text { conference) }\end{array}$ \\
\hline \multirow[t]{18}{*}{ STRATEGIC } & & Concepts \\
\hline & $4 \mathrm{~A}$ & Intentionality \\
\hline & $4 \mathrm{~B}$ & Transitions and transformations \\
\hline & $4 \mathrm{C}$ & $\begin{array}{c}\text { Strategies, action programs, (systemic) intervention, } \\
\text { transformative governance }\end{array}$ \\
\hline & $4 \mathrm{D}$ & Success factors, viability, feasibility, effectiveness, efficiency \\
\hline & $4 \mathrm{E}$ & Adaptation and mitigation \\
\hline & $4 \mathrm{~F}$ & $\begin{array}{c}\text { Obstacles (resistance, reluctance, path dependency, habits and } \\
\text { synergies) }\end{array}$ \\
\hline & $4 \mathrm{G}$ & Instrumentalization and alliances \\
\hline & $4 \mathrm{H}$ & Social learning \\
\hline & $4 \mathrm{I}$ & Social Movements \\
\hline & & Methodologies \\
\hline & $4 \mathrm{~J}$ & $\begin{array}{c}\text { Methods to design governance arrangements, policies } \\
\text { institutions }\end{array}$ \\
\hline & $4 \mathrm{~K}$ & Planning methodologies \\
\hline & $4 \mathrm{~L}$ & Decision Support methodologies \\
\hline & $4 \mathrm{M}$ & Transition Management methodologies \\
\hline & $4 \mathrm{~N}$ & Methods to support learning and reflexivity \\
\hline & $4 \mathrm{O}$ & Organizational (change) management \\
\hline & $4 \mathrm{P}$ & Methods to support Behaviour change \\
\hline
\end{tabular}


Table A1. Cont.

\begin{tabular}{|c|c|c|}
\hline COMPETENCE & CODES & COMPETENCY CONCEPTS AND METHODOLOGIES \\
\hline \multirow[t]{9}{*}{ INTERPERSONAL } & & Concept \\
\hline & $5 \mathrm{~A}$ & $\begin{array}{l}\text { Functions, types and dynamics of collaboration (within and } \\
\text { beyond academia, interdisciplinary, transdisciplinary) }\end{array}$ \\
\hline & $5 \mathrm{~B}$ & Strengths, weaknesses, success and failures in teams \\
\hline & $5 \mathrm{C}$ & Concepts of leadership \\
\hline & $5 \mathrm{D}$ & Limit of cooperation and leadership \\
\hline & $5 \mathrm{E}$ & Concepts of solidarity and ethnocentrism \\
\hline & & Methodologies \\
\hline & $5 \mathrm{~F}$ & $\begin{array}{l}\text { Participatory Methods, including negotiation, mediation, } \\
\text { deliberation, constructive conflict methodology }\end{array}$ \\
\hline & $5 \mathrm{G}$ & Teamwork Methods \\
\hline
\end{tabular}

\section{References}

1. Steffen, W.; Broadgate, W.; Deutsch, L.; Gaffney, O.; Ludwig, C. The trajectory of the Anthropocene: The Great Acceleration. Anthr. Rev. 2015, 2, 81-98. [CrossRef]

2. Lang, D.J.; Wiek, A.; Bergmann, M.; Stauffacher, M.; Martens, P.; Moll, P.; Swilling, M.; Thomas, C.J. Transdisciplinary research in sustainability science: Practice, principles, and challenges. Sustain. Sci. 2012, 7, 25-43. [CrossRef]

3. Broman, G.I.; Robèrt, K.-H. A framework for strategic sustainable development. J. Clean. Prod. 2017, 140, 17-31. [CrossRef]

4. Agbedahin, A.V. Sustainable development, Education for Sustainable Development, and the 2030 Agenda for Sustainable Development: Emergence, efficacy, eminence, and future. Sustain. Dev. 2019, 27, 669-680. [CrossRef]

5. Tarrant, M.A.; Rubin, D.L.; Stoner, L. The Effects of Studying Abroad and Studying Sustainability on Students' Global Perspectives. Front. Interdiscip. J. Study Abroad 2015, 26, 68-82. [CrossRef]

6. Redman, A.; Wiek, A.; Barth, M. Current Practice of Assessing Students' Sustainability Competencies-A Review of Tools. Unpublished 2020, in press.

7. Papenfuss, J.; Merritt, E.; Manuel-Navarrete, D.; Cloutier, S.; Eckard, B. Interacting Pedagogies: A Review and Framework for Sustainability Education. J. Sustain. Educ. 2019, 20, 19.

8. Lutterman-Aguilar, A.; Gingerich, O. Experiential Pedagogy for Study Abroad: Educating for Global Citizenship. Front. Interdiscip. J. Study Abroad 2002, 8, 41-82. [CrossRef]

9. Backman, M.; Pitt, H.; Marsden, T.; Mehmood, A.; Mathijs, E. Experiential approaches to sustainability education: Towards learning landscapes. Int. J. Sustain. High. Educ. 2019, 20, 139-156. [CrossRef]

10. Strange, H. An investigation of experiential and transformative learning in study abroad programs. Front. Interdiscip. J. Study Abroad 2017, 29, 85-100. [CrossRef]

11. Kolb, D. Experiential Learning: Experience as The Source of Learning and Development.pdf; Prentice Hall: Englewood Cliffs, NJ, USA, 1984.

12. Sipos, Y.; Battisti, B.; Grimm, K. Achieving transformative sustainability learning: Engaging head, hands and heart. Int. J. Sustain. High. Educ. 2008, 9, 68-86. [CrossRef]

13. Sandri, O.; Holdsworth, S.; Thomas, I. Vignette question design for the assessment of graduate sustainability learning outcomes. Environ. Educ. Res. 2018, 24, 406-426. [CrossRef]

14. Kinchin, I.M.; Cabot, L.B. Reconsidering the dimensions of expertise: From linear stages towards dual processing. Lond. Rev. Educ. 2010, 8, 153-166. [CrossRef]

15. Wals, A.E.J.; Geerling-Eijff, F.; Hubeek, F.; van der Kroon, S.; Vader, J. All Mixed Up? Instrumental and Emancipatory Learning Toward a More Sustainable World: Considerations for EE Policymakers. Appl. Environ. Educ. Commun. 2008, 7, 55-65. [CrossRef]

16. Brundiers, K.; Wiek, A. Beyond Interpersonal Competence: Teaching and Learning Professional Skills in Sustainability. Educ. Sci. 2017, 7, 39. [CrossRef]

17. Lozano, R.; Merrill, M.; Sammalisto, K.; Ceulemans, K.; Lozano, F. Connecting Competences and Pedagogical Approaches for Sustainable Development in Higher Education: A Literature Review and Framework Proposal. Sustainability 2017, 9, 1889. [CrossRef] 
18. Wiek, A.; Withycombe, L.; Redman, C.L. Key competencies in sustainability: A reference framework for academic program development. Sustain. Sci. 2011, 6, 203-218. [CrossRef]

19. Sterling, S.; Glasser, H.; Rieckmann, M.; Warwick, P. 10. "More than scaling up": A critical and practical inquiry into operationalizing sustainability competencies. In Envisioning Futures for Environmental and Sustainability Education; Corcoran, P.B., Weakland, J.P., Wals, A.E.J., Eds.; Wageningen Academic Publishers: Wageningen, The Netherlands, 2017; pp. 153-168. ISBN 978-90-8686-303-7.

20. Glasser, H. Toward the Development of Robust Learning for Sustainability Core Competencies. Sustain. J. Rec. 2016, 9, 121-134. [CrossRef]

21. Osagie, E.R.; Wesselink, R.; Blok, V.; Lans, T.; Mulder, M. Individual Competencies for Corporate Social Responsibility: A Literature and Practice Perspective. J. Bus. Ethics 2016, 135, 233-252. [CrossRef]

22. Savin-Baden, M.; Major, C.H. Qualitative Research: The Essential Guide to Theory and Practice. London: Routledge, 2013. Print.; Routledge: London, UK, 2013.

23. EWB. Humanitarian Design Summit Program. Available online: https://www.ewb.org.au/project/designsummit/ (accessed on 17 March 2020).

24. IDEO (Ed.) The Field Guide to Human-Centered Design: Design Kit, 1st ed.; IDEO: San Francisco, CA, USA, 2015; ISBN 978-0-9914063-1-9.

25. EWB. Design Summit Facilitator Toolkit; Engineers Without Borders, 2017.

26. Trencher, G.; Vincent, S.; Bahr, K.; Kudo, S.; Markham, K.; Yamanaka, Y. Evaluating core competencies development in sustainability and environmental master's programs: An empirical analysis. J. Clean. Prod. 2018, 181, 829-841. [CrossRef]

27. Lozano, R. Incorporation and institutionalization of SD into universities: Breaking through barriers to change. J. Clean. Prod. 2006, 14, 787-796. [CrossRef]

28. Wiek, A.; Bernstein, M.J.; Laubichler, M.; Caniglia, G.; Minteer, B.; Lang, D.J. A Global Classroom for International Sustainability Education. Creat. Educ. 2013, 4, 19-28. [CrossRef]

29. Broman, G.; Robèrt, K.-H.; Collins, T.J.; Basile, G.; Baumgartner, R.J.; Larsson, T.; Huisingh, D. Science in support of systematic leadership towards sustainability. J. Clean. Prod. 2017, 140,1-9. [CrossRef]

30. Lidar, M.; Lundqvist, E.; Östman, L. Teaching and learning in the science classroom: The interplay between teachers' epistemological moves and students' practical epistemology. Sci. Educ. 2006, 90, 148-163. [CrossRef]

31. Pacis, M.; Van Wynsberghe, R. Key sustainability competencies for education for sustainability: Creating a living, learning and adaptive tool for widespread use. Int. J. Sustain. High. Educ. 2020, in press. [CrossRef]

32. Wals, A.E.J. Learning Our Way to Sustainability. J. Educ. Sustain. Dev. 2011, 5, 177-186. [CrossRef] 